\title{
WILD VERTEBRATES ROADKILL AGGREGATIONS ON THE BR-050 HIGHWAY, STATE OF MINAS GERAIS, BRAZIL
}

\author{
AGREGAÇÕES DE ATROPELAMENTOS DE VERTEBRADOS SILVESTRES NA \\ RODOVIA BR-050, MINAS GERAIS, BRASIL
}

\author{
Carine Firmino CARVALHO'; Ana Elizabeth IANNINI CUSTÓDIO²; \\ Oswaldo MARÇAL JÚNIOR² \\ 1. Graduate in Ecology and Conservation of Natural Resources, Biology Institute, Uberlandia Federal University, Uberlandia, MG, \\ Brazil. carinefcarvalho@gmail.com; 2. Professor, Biology Institute, Uberlandia Federal University, Uberlandia, MG, Brazil.
}

\begin{abstract}
Researches on roadkill aggregations are important tools for wildlife conservation. The objective of this study was to determine wild vertebrate roadkill aggregations on a stretch of 96 kilometers of the BR-050 highway, between the cities of Uberlândia and Uberaba, State of Minas Gerais, Brazil. The survey was conducted between April 2012 and March 2013. Roadkill monitoring was performed by car, at a speed of approximately $60 \mathrm{~km} / \mathrm{h}$, and forty two (42) weekly trips, totaling $8064 \mathrm{~km}$, were performed. The 2D Ripley's K-Statistics test from the Siriema v1.1 program was used to detect the scales of roadkill aggregations and 2D HotSpot Identification test was used to identify the location of these hotspots. Aggregations extended from the following kms: 14 to 33, 38, 41 to 51, 66 to 70 and 78 to 94 . We found roadkill aggregations for wild vertebrates and mammals. The roadkill aggregations were significant for Euphractus sexcinctus, Conepatus semistriatus, Procyon cancrivorus, Hydrochoerus hydrochoerus, Cariama cristata, Boa constrictor amarali and Crotalus durissus collilineatus according to the taxonomic specific level. Thus, it is suggested that mitigation measures for vertebrate conservation must be implemented in the indicated areas.
\end{abstract}

KEYWORDS: Road Ecology. Roadkill hotspots. Cerrado. Conservation. Mitigation measures.

\section{INTRODUCTION}

Wildlife roadkill on highways causes biodiversity losses in intensities impossible to quantify efficiently (BAGER; FONTOURA, 2012). In Brazil alone it is estimated that 473 million of vertebrates die victims of vehicle accidents per year (CBEE, 2014). Local populations may decline where the indices of roadkill exceed those of reproduction and immigration (FORMAN; ALEXANDER, 1998). Moreover, linear developments have a strong impact on wildlife by preventing or hindering gene flow between populations. This may lead to local extinctions, resulting from demographic effects and genetic and environmental changes (LAURANCE et al., 2009).

Basically the type of locomotion, ecology and animal behavior determine the species vulnerability to roadkill (LAURANCE et al., 2009; CÁCERES 2011). The majority of the species that forage in the vicinity of the roads are more vulnerable to roadkill, which includes many predators, scavengers and herbivores that feed on grasses (COFFIN, 2007; LAURANCE et al., 2009). Mammals are victims of roadkill when they transit along highways that are crossing their home range or when they are attracted to available resources in the surrounding area (LAURANCE et al., 2009). Birds are attracted to roads by the availability of perches in the roads surroundings, by the abundance of small mammals that serve them as food, by grain falling from vehicles and by roadkill carcasses (GRILO et al., 2010). The main risks of roadkill for reptiles are associated with slow movements and the behavior of heating themselves on the roads as a means of thermoregulation (LAURANCE et al, 2009; GRILO et al, 2010).

Besides biology and animal ecology, several other factors influence roadkill, including high vehicle speeds, volume of traffic, road width, presence of curves, floor type, topography and vegetation surrounding the highway (FORMAN; ALEXANDER, 1998, LAURANCE et al, 2009; GRILO et al, 2010). Because of all these factures, vertebrate roadkill patterns are usually nonrandom. Another factor that influence this pattern is that animals use the same routes to move from place to place (MALO et al. 2004).

In this context, the detection of aggregation areas (hotspots), through analyses, using geographic positioning of roadkill, makes it possible to know where to install the targeted mitigation measures, such as warning signs, electronic barriers, speed bumps, olfactory repellent, light and sound, fencing and wildlife crossings (GLISTA et al, 2009; GRILO et al, 2010; VAN DER GRIFT et al., 2013). Since it is not financially viable for most governments develop strategies that mitigate roadkill along the total length of all roads (GOMES et al., 2008), road managers need reliable data to identify when and 
where certain species are susceptible to high roadkill rates in order to implement mitigation measures at these sites (GRILO et al., 2009).

The present study was undertaken to determine wild vertebrate roadkill aggregations on a stretch of the BR-050 highway, between the cities of Uberlândia and Uberaba, State of Minas Gerais, in the Cerrado biome, and to propose mitigation measures for the local fauna.

\section{MATERIAL AND METHODS}

\section{Study area}

The cities of Uberlandia and Uberaba are situated in the area of Highlands and Plateaus of the Paraná Sedimentary Basin, being inserted into the subunit of the Southern Plateau of the Paraná Basin (SEDET, 2009). The area is included in the Cerrado biome; however, the natural vegetation types (forests, savannas and veredas or palm swamps) are quite fragmented, with a landscape dominated by pasture and agricultural crops (e.g. sugar cane, corn and soybean). The climate is Aw, according to the Köppen classification, showing seasonal traits with a rainy summer season from October to April and a dry winter season from May to September (ROSA et al., 1991), with average temperatures between $17^{\circ} \mathrm{C}$ and $23{ }^{\circ} \mathrm{C}$, annual temperature range between $7{ }^{\circ} \mathrm{C}$ and $9^{\circ} \mathrm{C}$, and relative humidity of the air ranging between 40 and $80 \%$.

The BR-050 highway extends through more than $1,000 \mathrm{~km}$, from Brasília (Federal District) to the State of São Paulo (SP-330), passing through the States of Goiás and Minas Gerais. The stretch investigated is located between the cities of Uberlândia and Uberaba, Minas Gerais, with 96 km of highway duplicated in both directions (Figure 1). On average, 12,000 vehicles pass daily on this stretch of the highway (SEDET, 2009).

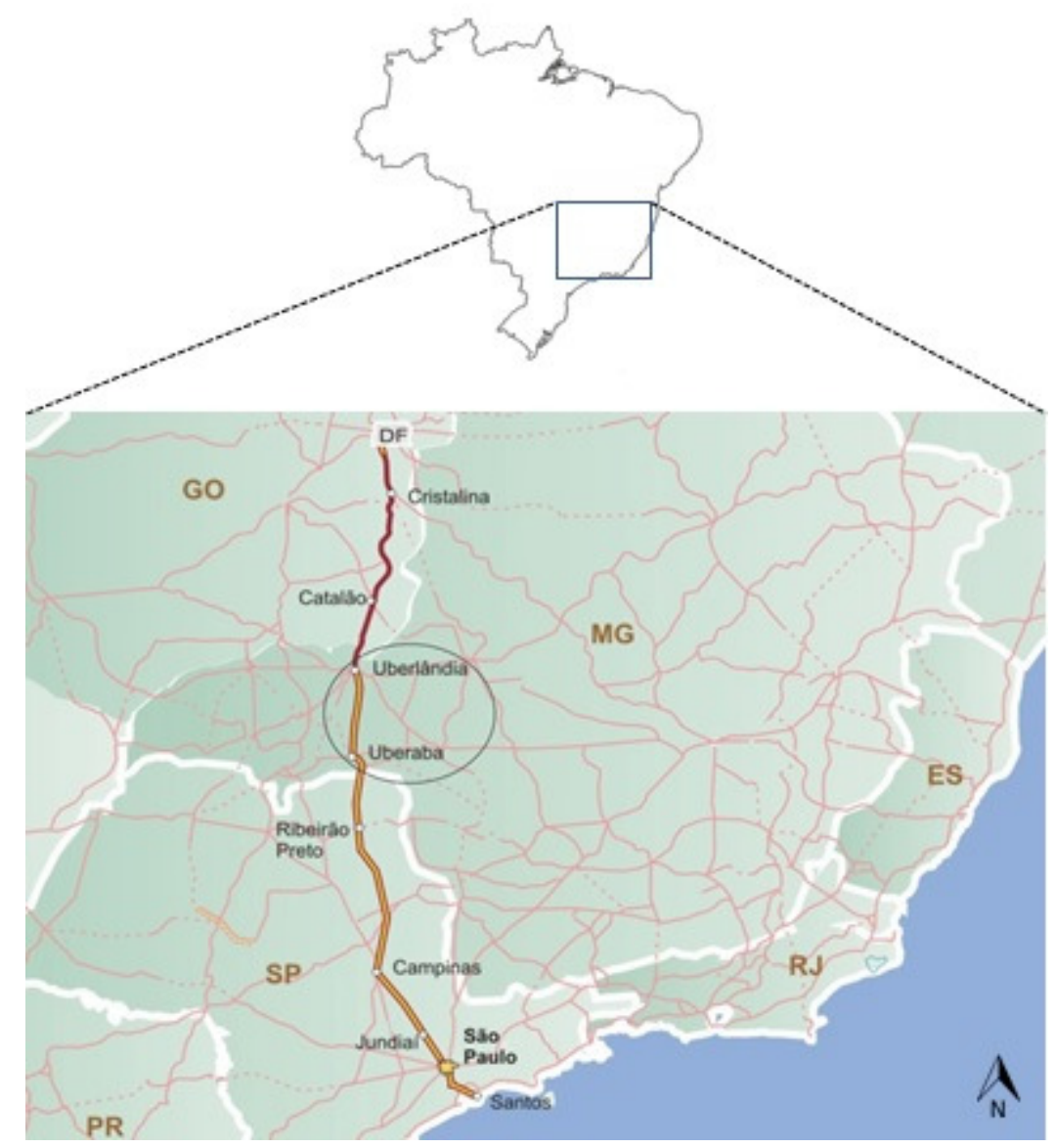

Figure 1. Location of the BR-050 highway, especially the section investigated, between the municipalities of Uberlândia and Uberaba (in the circle). Source: Brazil, Transport Ministry (2012).

\section{Monitoring}

The survey was performed between April 2012 and March 2013. The monitoring was done by car, at a speed of approximately $60 \mathrm{~km} / \mathrm{h}$, and forty two (42) weekly trips, totaling $8,064 \mathrm{~km}$ performed. Two people observed the road looking for roadkill animals. Roadkill records were identified at the lowest possible taxonomic level. Mammals were 
identified according to Reis et al. (2010). Birds were identified and named according to Sigrist (2009) and CBRO (2011). For reptiles, Bérnils and Costa (2012) was used. Due to their small size and low detectability amphibians were not included in the survey.

Photographic records of the majority of the specimens found were made. To determine the conservation status of these animals, Drummond (2008) for the State of Minas Gerais, ICMBio (2013) for Brazil and IUCN (2013) for worldwide were used.

The geographic coordinates of roadkill records were determined using GPS. After each registration, the carcass was removed from the highway to avoid subsequent recount and scavengers being killed, according to Costa (2011), Cáceres et al. (2012) and Hegel et al. (2012).

\section{Data Analysis}

The 2D Ripley's K-Statistics test from Siriema v1.1 software was used to determine the existence of roadkill aggregations (roadkill hotspots) and the scale of same (COELHO et al., 2011). An initial radius of 100 meters, a radius increase of 500 meters, confidence level of $95 \%$ and a thousand simulations were used. The values of initial radius and radius increment corresponded to the scale at which mitigation measures can be effective (TEIXEIRA et al., 2013). The program tests the existence or not of roadkill aggregations in different scales (COELHO et al., 2011). The 2D HotSpot Identification test was used to identify where the roadkill aggregations are localized (COELHO et al., 2011). A radius of four kilometers was used because this was the smallest radius at which the roadkill aggregations were significant, according to the results of the 2D Ripley KStatistics test, a confidence level of $95 \%$ and a thousand simulations.

The Siriema program also allows to set different weights for each roadkill record (COELHO et al., 2011). This tool was applied to value the endangered species, which received weight two, the other species received weight one. For all analysis, the following taxa was considered separately: Vertebrate, Mammalia, Aves, Lepidosauria and the 10 wild species with the highest number of roadkill records (Cerdocyon thous, Euphractus sexcinctus, Conepatus semistriatus, Procyon cancrivorus, Tamandua tetradactyla, Hydrochoerus hydrochaeris, Dasypus novemcinctus, Cariama cristata, Boa constrictor amarali and Crotalus durissus collilineatus).

\section{RESULTS}

A total of 683 roadkill vertebrates was found, including: 482 mammals (70.6\%), 145 birds (21.2\%) and 56 reptiles (8.2\%). At species level, 57 taxa were identified, being 21 mammals, 26 birds and 10 reptiles.

Roadkill aggregations were identified for both vertebrates and mammals. Birds and reptiles separately did not show such roadkill hotspots (Figure 2).

The aggregations for vertebrates were recorded between $\mathrm{km}: 16$ to $25,38,83$ to 84,85 to 86 and 87 to 89 . They were more intense between $\mathrm{km} 20$ to 22 (Figure 3). For mammals, these aggregations extend across $\mathrm{km}: 16$ to 27,82 to 84 , 87 to 89 ; with greater intensity between $\mathrm{km} 18$ to 24 (Figure 3). There was no aggregation point for the groups and species searched between $\mathrm{km}: 0$ to 14, 33 to 38,38 to 41,51 to 66,70 to 78 and 94 to 96 (Figure 3).

Roadkill hotspots at specific levels were found for Euphractus sexcinctus, Conepatus semistriatus, Procyon cancrivorus, Hydrochoerus hydrochaeris (Mammalia); Cariama cristata (Aves); Boa constrictor amarali and Crotalus durissus collilineatus (Lepidosauria) (Figure 2). For the last species it is worth noting that aggregations occurred only in the radius bigger than $20 \mathrm{~km}$ (therefore, these hotspots are not shown in Figure 3). Tamandua tetradactyla and Dasypus novemcinctus showed no aggregations in the study area (Figure 2).

Three roadkill aggregations were found for Euphractus sexcinctus at $\mathrm{km}: 14$ to 25,38 and 41 to 43 ; with greater intensity between the $\mathrm{km} 16$ to 22. For Conepatus semistriatus, roadkill hotspots were found at $\mathrm{km}$ : 42 to 51,66 to 68 and 83 to 87 , with higher intensity between $\mathrm{km} 45$ to 48 . For Procyon cancrivorus, roadkill aggregations were situated between km: 20 to 31 and 32 to 33, with greater intensity between $\mathrm{km} 23$ to 24 . For Hydrochoerus hydrochaeris, roadkill aggregations were located between $\mathrm{km}: 83$ to 91, with higher intensity at $\mathrm{km} 87$ and 88 . For Cariama cristata, roadkill hotspots extended from km: 62 to 70 . From Boa constrictor amarali roadkill aggregations were localized between $\mathrm{km}: 78$ to 80,81 to 84 and 85 to 94 (Figure 3). 


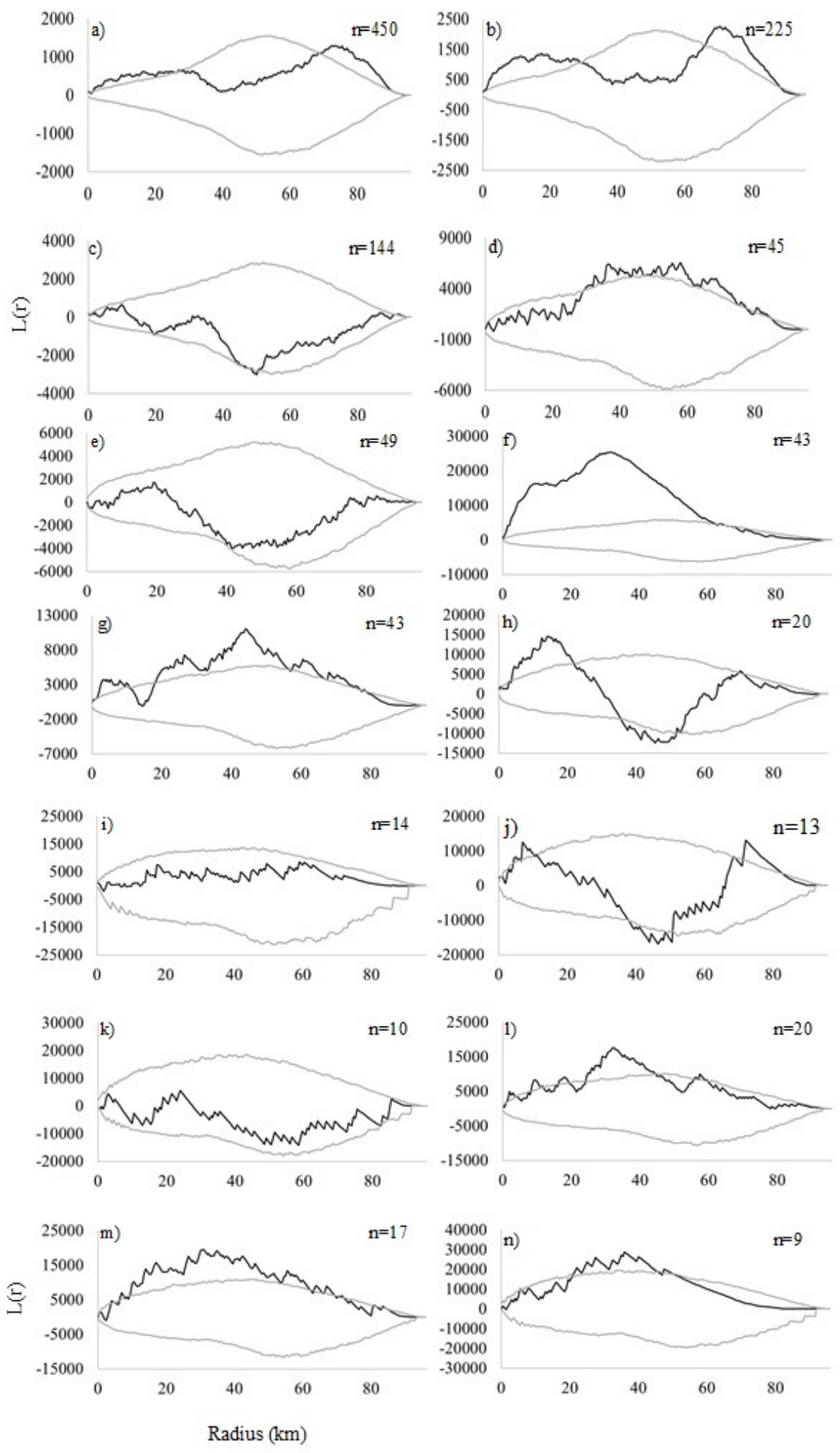

Figure 2. Roadkill aggregations according to radius. There is aggregation when the function L(r) (black Line) is above the upper confidence limit (gray line). Results from the 2D Ripley's K-Statistics test a) wild vertebrates, b) wild mammals, c) birds, d) reptiles, e) Cerdocyon thous, f) Euphractus sexcinctus, g) Conepatus semistriatus, h) Procyon cancrivorus, i) Tamandua tetradactyla, j) Hydrochoerus hydrochaeris, k) Dasypus novemcinctus, 1) Cariama cristata, m) Boa constrictor amarali, n) Crotalus durissus collilineatus. 


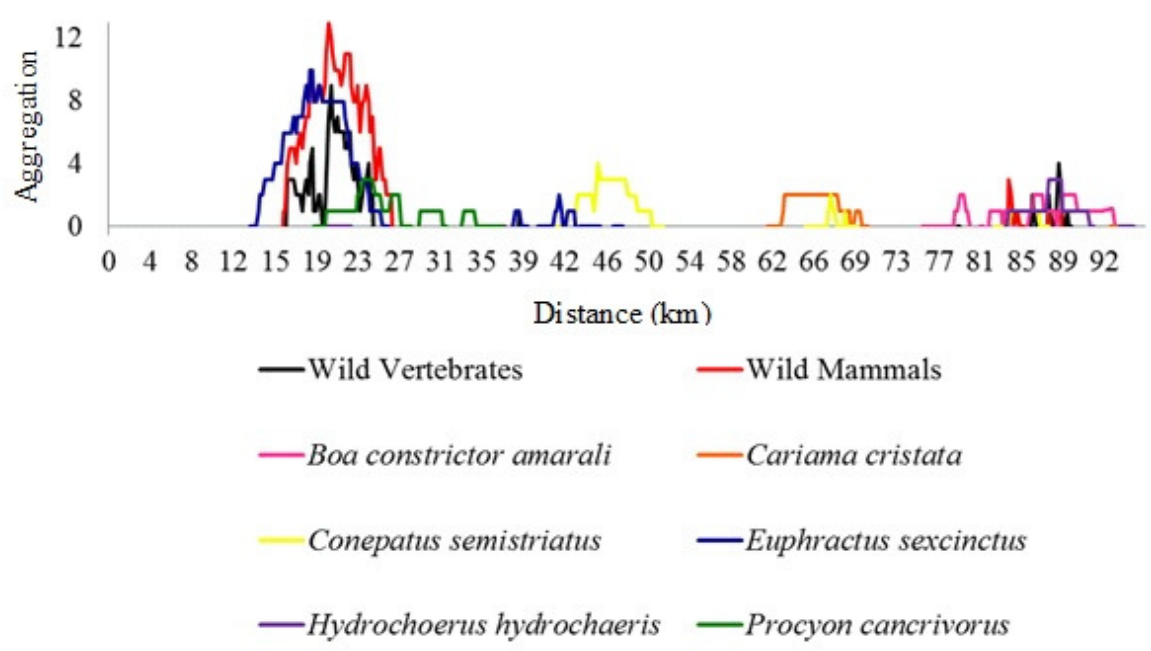

Figure 3. Wild vertebrate roadkill aggregations on the BR-050 highway, stretch Uberlândia-Uberaba, MG (2012-2013). Kilometer zero was in Uberlândia and the final kilometer (km 96) in Uberaba. Results from the 2D HotSpot Identification test.

\section{DISCUSSION}

Recent studies have showed wild vertebrates roadkill aggregations in Brazil and worldwide (CLEVENGER et al., 2003; COELHO et al., 2008; CÁCERES et al., 2012; TEIXEIRA et al., 2013). Coelho and colleagues (2008) showed that roadkill of vertebrates, mammals and birds occurs in aggregated form in the Atlantic Forest. In the Cerrado, Cáceres and colleagues (2012) have also located roadkill aggregations for wild mammals. Teixeira and colleagues (2013) found significant roadkill aggregations for wild mammals, birds and reptiles.

Freitas and colleagues (2013) found difficulty in relating birds roadkill with landscape features surrounding the highway due to the high diversity and low abundance of bird roadkills. This same hypothesis, high diversity and low abundance of bird roadkills, can be suggested to explain the no occurrence of bird and reptile roadkill hotspots in this research. Only Cariama cristata and Boa constrictor amarali showed aggregations among the species of birds and reptiles studied, respectively.

Cáceres and colegues (2012) located roadkilll aggregation for Cerdocyon thous, Tamandua tetradactyla e Dasypus novemcinctus. but they did not find roadkill aggregation for Euphractus sexcinctus. According to Clevenger et al. (2003), roadkill aggregations may reflect different responses of animals to their habitat, spatial and temporal variation in habitat quality or local soil conditions that may facilitate or block the movement across roads.

A selection of stretches for the implementation of roadkill mitigation measures should be made with caution, so that important areas are not eliminated during the selection process (BAGER et al., 2010). The adequate location of wildlife crossings, for example, can improve or maintain connectivity between animal populations (LESBARRÈRES; FAHRIG, 2012; VAN DER GRIFT et al., 2013). Significant roadkill hostspots found for vertebrates, mammals, and for some species indicate that mortality is concentrate on some segments of the road and, therefore, certain areas are better than others to implement mitigation measures (Coelho et al., 2008). A higher intensity of roadkill aggregations on the highway searched was observed in the stretch between $\mathrm{km} 18$ to 24, suggesting that this area should be prioritized in the adoption of possible mitigation measures. The construction of wildlife crossings in conjugation with fencing to direct animals and prevent them from crossing the highway is recommended (BAGER, 2003; GLISTA et al., 2009; GRILO et al., 2010; VAN DER GRIFT et al., 2013). This technique brings the great advantage of preventing roadkill and ensuring the maintenance of gene flow between animal populations, however this is very expensive (GLISTA et al., 2009; GRILO et al., 2010; VAN DER GRIFT et al., 2013) and its application in a road that already exists is difficult. Another option would be to use water pipe runoff, which can be modified, installing non-flooded side platforms, so small wild animals can be able to use 
them to go through dry ledges (GRILO et al., 2010). It is a low cost alternative (MATA et al., 2008; LAUXEN 2012). This stretch of the highway, as from the year 2014, is under concession and partnerships with the concessionary can be performed. However, the least expensive mitigation measures are warning signs, electronic barriers, speed bumps and awareness campaigns (GLISTA et al, 2009; GRILO et al, 2010).

In addition to long-term mitigation measures, we encourage the development of an environmental education program targeted at highway users. According to Bager (2003), a great part of the wildlife roadkill could be minimized through environmental awareness. The timely mowing of verge vegetation should also be encouraged, which decreases the chance of the fauna moving along the roadside and increases the possibility of animal visualization and the reaction time of drivers (BAGER, 2003; LAUXEN, 2012). Furthermore, the verge vegetation can serve as a habitat for some species, and attract them to the highway increasing roadkill risk (ASCENSÃO et al., 2012). Another measure that can be implemented is to remove the roadkill carcasses, because this activity could decrease the number of scavengers roadkill (FREITAS, 2009)

In addition of knowing where roadkill aggregations are located, it is necessary to understand what parameters influence the roadkill such as topography, landscape surrounding the highway, human disturbance (GRILO et al., 2009; LAURANCE et al., 2009; GRILO et al., 2010). Therefore, it becomes essential to investigate the factors involved in the roadkill dynamics, aiming to create predictive models of roadkill that guide the construction, operation and renovation of roads making them effective in the protection and conservation of wildlife (BUENO et al., 2012).

It is suggested that studies with a longer duration of monitoring be conducted to compare if a year of monitoring is sufficient to detect roadkill patterns. In practice, the monitoring period performed by companies is much smaller than a year.

\section{ACKNOWLEDGEMENT}

To CAPES for granting the Master degree scholarship to the main author of this work.

RESUMO: Pesquisas sobre agregações de atropelamento são ferramentas importantes para a conservação da vida selvagem. O objetivo deste estudo foi determinar agregações de atropelamentos de vertebrados silvestres em um trecho de $96 \mathrm{~km}$ da rodovia BR-050, entre as cidades de Uberlândia e Uberaba (MG), na região central do Brasil. A pesquisa foi realizada a partir de abril de 2012 a março de 2013. O monitoramento foi realizado de carro e o trecho foi investigado a uma velocidade de aproximadamente $60 \mathrm{~km} / \mathrm{h}$. Realizamos 42 viagens semanais, num total de $8064 \mathrm{~km}$ percorridos. O teste 2D Ripley's K-Statistics do programa Siriema v1.1 foi utilizado para detectar as escalas de agregações de atropelamentos e o teste 2D HotSpot Identification foi utilizado para identificar a localização destes hotspots. Agreagações de atropelamento se extenderam nos seguintes quilômetros: 14-33, 38-41 a 51, 66 a 70 e 78-94. Encontramos agregações de vertebrados e mamíferos silvestres. Em nível taxonômico específico foram encontradas agregações de atropelamentos significativas para Euphractus sexcinctus, Conepatus semistriatus, Procyon cancrivorus, Hydrochoerus hydrochaeris, Cariama cristata, Boa constrictor amarali, Crotalus durissus collilineatus. Assim, sugere-se que medidas de mitigação para a conservação de vertebrados devem ser implementadas nas áreas indicadas.

PALAVRAS-CHAVES: Ecologia de Estradas. Agregações de atropelamentos. Cerrado. Conservação. Medidas de mitigação.

\section{REFERENCES}

ASCENSÃO, F.; CLEVENGER, A. P.; GRILO, C.; FILIPE, J.; SANTOS-REIS, M. Highway verges as habitat providers for small mammals in agrosilvopastoral environments. Biodiversity and Conservation, London, v. 21, p. 3681-3697, 2012. http://dx.doi.org/10.1007/s10531-012-0390-3

BAGER, A. Repensando as medidas mitigadoras impostas aos empreendimentos rodoviários associados a unidades de conservação - um estudo de caso. In: BAGER, A (ed). Conservação no âmbito do Cone Sul. Pelotas: Alex Bager, 2003. p. 160-172.

BAGER, A.; ROSA, C. A. Priority ranking of road sites for mitigating wildlife roadkills. Biota Neotropica, Campinas, v. 10, p. 149-154, 2010. http://dx.doi.org/10.1590/S1676-06032010000400020 
BAGER, A.; FONTOURA, V. Ecologia de estradas no Brasil- Contexto histórico e perspectivas futuras. In: BAGER, A. (ed.) Ecologia de Estradas: tendências e pesquisas. Lavras: Ed. UFLA, 2012. p. 13-33.

BÉRNILS, R. S.; COSTA, H. C. (org.). 2012. Répteis brasileiros: Lista de espécies. Versão 2012.2. Sociedade Brasileira de Herpetologia. Disponível em $<\underline{\mathrm{http}} / / / \mathrm{www}$.sbherpetologia.org.br/ $>$. Acesso em junho de 2013.

BRASIL. BR-050. Disponível em: < http://www2.transportes.gov.br/bit/02-rodo/3-loc-rodo/loc-rodo/050.htm $>$. Acesso em dezembro de 2013.

BUENO, C.; FREITAS, L. E.; COUTINHO, B. H.; OSWALDO CRUZ, J. H.; CASTRO JÚNIOR, E. de. A distribuição especial de atropelamentos de fauna silvestre sua relação com a vegetação: Estudo de caso da rodovia BR-040. In: BAGER, A. (ed.) Ecologia de Estradas: tendências e pesquisas. Lavras: Ed. UFLA, 2012. p. 167-178.

CÁCERES, N. C. Biological characteristics influence mammal road kill in an Atlantic Forest-Cerrado interface in south-western Brazil. Italian Journal of Zoology, Modena, v. 78, p. 379-389, 2011. http://dx.doi.org/10.1080/11250003.2011.566226

CÁCERES, N. C.; CASELLA, J.; GOULART, C. S. Variação espacial e sazonal de atropelamentos e mamíferos no bioma cerrado, rodovia BR 262, Sudoeste do Brasil. Mastozoología Neotropical, Mendoza, v. 19, n. 1, p.21-33, 2012.

CBEE. Atropelômetro. Disponível em <http://cbee.ufla.br/portal/index.php>. Acesso em julho de 2014.

CBRO. Listas das aves do Brasil. 10ª Edição. Disponível em <http://www.cbro.org.br $>$. Acesso em: maio de 2014.

CLEVENGER, A. P; CHRUSZCZ, B.; GUNSON, K. E. Spatial patterns and factors influencing small vertebrate fauna road-kill aggregations. Biological Conservation, Boston, v. 109, p. 15-26, 2003. http://dx.doi.org/10.1016/S0006-3207(02)00127-1

COELHO, I. P.; KINDEL, A.; COELHO, A. V. P. Roadkills of vertebrate species on two highways through the Atlantic Forest Biosphere Reserve, southern Brazil. European Journal of Wildlife Research, Berlin, v. 54, p. 689-699, 2008. http://dx.doi.org/10.1007/s10344-008-0197-4

COELHO, A. V. P. ; COELHO, P. I ; KINDEL, A. ; TEIXEIRA, F. Z. Siriema: Manual do Usuário v1.1. Universidade Federal do Porto Alegre, Rio Grande do Sul, 2011. 23 p.

COFFIN, A. W. From roadkill to road ecology: A review of the ecological effects of roads. Journal of Transport Geography, London, v. 15, p. 396-406, 2007. http://dx.doi.org/10.1016/j.jtrangeo.2006.11.006

COSTA, L. de S. C. Levantamento de mamíferos silvestres de pequeno e médio porte atropelados na BR 101, entre os municípios de Joinville E Piçarras, Santa Catarina. Bioscience Journal, Uberlândia, v. 27, n. 3, p. 666672, 2011.

DRUMMOND, G. M.; MACHADO, A. B. M.; MARTINS, C. S.; MENDONÇA, M. P.; STEHMAN, J. R. (eds.) Listas vermelhas das espécies da fauna e da flora ameaçadas de extinção em Minas Gerais. $2^{\text {nd }}$ ed. Belo Horizonte: Fundação Biodiversitas, 2008.

FORMAN, R.T.T.; ALEXANDER, L.E. Roads and their major ecological effects. Annual Review of Ecology and Systematics, Palo Alto, p. 207-232, 1998. 
FREITAS, C. H. Atropelamento de vertebrados nas rodovias MG-428 e SP-334 com análise dos fatores condicionantes e valoração econômica da fauna. 2009. 106 f. Tese (Doutorado em Ciências Biológicas) Instituto de Biociências, Universidade Estadual Paulista, Rio Claro. 2009.

FREITAS, S. R. ; SOUSA, C. O. M.; BUENO, C. Effects of landscape characteristics on roadkill of mammals, birds and reptiles in a highway crossing the Atlantic Forest in southeastern Brazil. In: International Conference on Ecology and Transportation (ICOET 2013), 7, 2013, Arizona, Estados Unidos, Proceedings ... 2013. Disponível em: <http://www.icoet.net/ICOET_2013/proceedings.asp $>$.

GLISTA, D. J.; DEVAULT, T. L; DEWOODY, J. A. A review of mitigation measures for reducing wildlife mortality on roadways. Landscape and Urban Planning, Amsterdam, p. 1-7, 2008.

GOMES, L.; GRILO, C.; MIRA, C. S. A. Identification methods and deterministic factors of owl roadkill hotspot locations in Mediterranean landscapes. Ecology Research. Ecological Research, Sakura-Mura, v. 24, p. 355-370, 2009.

GRILO, C.; BISSONETTE, J. A.; SANTOS-REIS, M. Spatial-temporal patterns in Mediterranean carnivore road casualties: Consequences for mitigation. Biological Conservation, Boston, v. 142, p. 301-313, 2009. http://dx.doi.org/10.1016/j.biocon.2008.10.026

GRILO, C.; BISSONETTE, J. A.; CRAMER, P. C. Mitigation measures to reduce impacts on biodiversity. In: JONES, R. S (ed.). Highways: constructions, management and maintenance. New York: Nova Science Publishers, 2010. p. 73-114.

HEGEL, C. G. Z.; CONSALTER, G. C.; ZANELLA, N. Mamíferos silvestres atropelados na rodovia RS-135, norte do Estado do Rio Grande do Sul. Biotemas, Florianópolis, v. 25, n. 2, p. 165-170, 2012.

ICMBIO. Lista de espécies ameaçadas. Disponível em:

$<$ http://www.icmbio.gov.br/portal/biodiversidade/fauna-brasileira/lista-de-especies.html>. Acesso em: março de 2014.

IUCN. The IUCN red list of threatened species. 2012. Disponível em: <http://www.iucnredlist.org/>. Acesso em: março de 2014.

LAURANCE, W. F.; GOOSEM, M; LAURANCE, S. G. W. Impacts of roads and linear clearing on tropical forests. Trends in Ecology and Evolution, Amsterdam, v. 24, n. 12, p. 659-669, 2009.

http://dx.doi.org/10.1016/j.tree.2009.06.009

LAUXEN, M. S. A mitigação dos impactos de rodovias sobre a fauna: um guia de procedimentos para tomada de decisão. 2012. Especialização em Diversidade e Conservação da Fauna - Departamento de Zoologia, Universidade Federal do Rio Grade do Sul, Porto Alegre, Rio Grande do Sul, 2012.

LESBARRÈRES, D.; FAHRIG, L. Measures to reduce population fragmentation by roads: what has worked and how do we know? Trends in Ecology and Evolution, Amsterdam, v. 27, n. 7, p. 374-380, 2012. http://dx.doi.org/10.1016/j.tree.2012.01.015

MALO, J. E.; SUÁREZ, F.; DÍEZ, A. Can we mitigate animal-vehicle accidents using predictive models? Journal of Applied Ecology, London, v. 41, p. 701-71, 2004. http://dx.doi.org/10.1111/j.00218901.2004.00929.x

MATA, C. et al. Are motorway wildlife passages worth building? Vertebrate use of road-crossing structures on a Spanish motorway. Journal of Environmental Management, Oxford, v. 88, p. 407-41, 2008. http://dx.doi.org/10.1016/j.jenvman.2007.03.014 
REIS, N. R; PERACCHI, A. L.; FREGONEZI, M. N.; ROSSANEIS, B. K. Mamíferos do Brasil -guia de identificação. Rio de Janeiro: Technical Books Editora, 2010. 577p.

ROSA, R.; LIMA, S. C.; ASSUNÇÃO, W. L. Abordagem preliminar das condições climáticas de Uberlândia (MG). Sociedade e natureza, Uberlândia, v. 3, p. 91-108, 1991.

SEDET. 2009. Uberaba em dados. Disponível em: <http://www.uberaba.mg.gov.br/portal/conteudo,232 $>$. Acesso em julho de 2013.

SIGRIST, T. Avifauna brasileira: pranchas e mapas. São Paulo: Avis Brasilis, 2009. 492p.

TEIXEIRA, F. Z.; COELHO, I. P.; ESPERANDIO, I. B.; OLIVEIRA, N. R.; PETER, F. P.; DORNELES, S. S.; DELAZERI, N. R.; TAVARES, M.; MARTINS, M. B.; KINDEL, A. Are road-kill hotspots coincident among different vertebrate groups?. Oecologia Australis, Berlin, v. 17, p. 36-47, 2013.

http://dx.doi.org/10.4257/oeco.2013.1701.04

VAN DER GRIFT, E. A.; VAN DER REE, R.; FAHRIG, L.; FINDLEY, S.; HOULAHAN, J.; JAEGER, J.A.G.; KLAR, N.; MADRIÑAN, L. F.; OLSEN, L. Evaluating the effectiveness of road mitigation measures.

Biodiversity and Conservation, London, v. 22, p. 425-448, 2013. http://dx.doi.org/10.1007/s10531-012-04210 